- Минимальную передаваемую величину $10^{-8}$ биткоина называют «сатоси» - в честь создателя Сатоси Накамото, хотя сам он использовал для обозначений минимальной передаваемой величины слово «цент».

- Оборот сайта Silk Road за два с половиной года работы оценивался ФБР в 9,5 млн биткоинов. Это число лишь немногим меньше, чем общее количество биткоинов (на октябрь 2013 года) - 11,75 млн. Такое соотношение может свидетельствовать о том, что основным использованием криптовалюты (кроме чисто спекулятивных применений) была покупка нелегальных товаров, в том числе наркотиков.

От автора.Существованием вышеописанной цифровой валюты интересуются спецслужбы разных стран мира. Почему? На наш взгляд, в первую очередь причиной являются транзакции за оплату незаконных услуг и товаров. Да, при правильном подходе - использование данной валюты покупателем и продавцом невозможно отследить. С помощью Bitcoin можно оплатить любую незаконную услугу, производить финансирование различных незаконных организаций и т.д. Эта сторона вопроса - негативная, но есть и другие.

Каждый денежный перевод через банки на территории страны и вне ее пределов - осуществляется с отчислением процентов банку. Хотите вы отправить $1000 \$$ родителям за границу - платите процент за перевод средств, хотите что-то купить в интернет-магазине или у частного лица - платите процент за перевод средств. По большому счету эти проценты в некотором смысле поддерживают жизнедеятельность банков и платежных систем. Зачем кому-либо платить больше? Перевод средств через платежные системы Bitcoin не требует отчисления процентов.

На данный момент уже существует множество интернет-магазинов и сервисов предоставления законных услуг за ВТС. Их количество растет с каждым днем. При использовании данной цифровой валюты многие сервисы и магазины программно автоматизируют свою деятельность. Если их товар нематериален, то существует возможность полной автоматизации, т.е. без участия человеческого труда. Единственный и самый большой «минус» данной цифровой валюты - нестабильность курса относительно к реальным валютам. Также (лично для меня) не закрытым остается вопрос: «Действительно ли никто не контролирует Bitcoin?»

Література

1. Web: http://ru.wikipedia.org/wiki/Bitcoin

2. Web: http://bitcoin.at.ua/

Удк: 62-503.5

\title{
ПРИНЦИП РОБОТИ ЧАСТОТНОГО ПЕРЕТВОРЮВАЧА
}

\author{
Соколова К. А. \\ Одеська національна академія харчових технологій, м. Одеса
}

Анотація: Дана стаття присвячена ознайомленню з поняттям «Частотний перетворювач». Так само в даній статті описуються принцип роботі частотного перетворювача.

Annotation: This article is devoted to familiarization with the concept of "frequency converter". Also in this paper describes the principle of operation of the frequency converter.

Ключові слова: перетворювач, автоматизація , частота.

Частотний перетворювач 3 широтно-імпульсним управлінням (ПП з ШІМ) знижує пускові струми в 4-5 разів. Він забезпечує плавний пуск асинхронного двигуна і здійснює управління приводом по заданій формулі співвідношення напруга / частота.

Частотний перетворювач дає економію за споживанням енергії до $50 \%$ З'являється можливість включення зворотних зв'язків між суміжними приводами, тобто самонастроювання обладнання під поставлену задачу і зміна умов роботи всієї системи.

Принцип роботи частотного перетворювача 
Частотний перетворювач з ШІМ являє собою інвертор з подвійним перетворенням напруги. Спочатку мережеве напруга 220 або 380 В випрямляється вхідним доданими мостом, потім згладжується і фільтрується за допомогою конденсаторів .

Це перший етап перетворення. На другому етапі з постійної напруги , за допомогою мікросхем управління і вихідних мостових IGBT ключів, формується ШІМ послідовність певної частоти і шпаруватості . На виході частотного перетворювача видаються пачки прямокутних імпульсів , але за рахунок індуктивності обмоток статора асинхронного двигуна , вони інтегруються і перетворюються нарешті в напругу близьке до синусоїди .

Критерії вибору частотних перетворювачів

Вибір за функціями Кожен виробник намагається забезпечити собі конкурентну перевагу на ринку. Перше правило для забезпечення максимуму продажів - це низька ціна. Тому виробник прагнути включити в свій виріб тільки необхідні функції. А решта пропонує в якості опції. Перш ніж купити частотний перетворювач, визначитеся, які функції вам потрібні. Варто вибирати той прилад, який має більшість необхідних функцій в базовому варіанті.

За способом управління

Відразу відкидайте ті перетворювачі , які не підходять по потужності , типом виконання , перевантажувальної здатності і т.д. За типом управління , потрібно визначитися , що вибрати, скалярний або векторне управління .

Більшість сучасних частотних перетворювачів реалізують векторне управління , але такі частотні перетворювачі дорожче , ніж частотні перетворювачі зі скалярним керуванням.

Векторне управління дає можливість більш точного управління , знижуючи статичну помилку . Скалярний режим тільки підтримує постійне співвідношення між вихідним напруга і вихідний частотою , але наприклад , для вентиляторів це цілком достатньо.

За потужністю

Якщо потужності устаткування приблизно однакові, то вибирайте перетворювачі однієї фірми 3 потужністю по потужності максимального навантаження. Так ви забезпечите взаємозамінність і спростите обслуговування обладнання . Бажано , щоб сервіс центр обраного частотного перетворювача був у вашому місті.

По мережевому напрузі

Завжди вибирайте перетворювач з максимально широким діапазоном напруг як вниз , так і вгору. Справа в тому , що для вітчизняних мереж саме слово стандарт може викликати тільки сміх крізь сльози. Якщо знижена напруга призведе, швидше за все , до відключення частотного перетворювача, то підвищена може викликати вибух мережевих електролітичних конденсаторів і входу приладу з ладу.

По терміну гарантії

Термін гарантії побічно дозволяє оцінити надійність частотного перетворювача. Природно, потрібно вибирати частотний перетворювач 3 великим терміном. Деякі виробники обумовлюють особливо випадки поломок, які не $\epsilon$ гарантійними. Завжди ретельно читайте документацію і подивіться в інтернеті відгуки про моделі і виробниках обладнання. Це допоможе правильному вибору. Не шкодуйте грошей на якісний сервіс і навчання персоналу..

\section{Структура частотного перетворювача}

Більшість сучасних перетворювачів частоти побудовано за схемою подвійного перетворення . Вони складаються 3 наступних основних частин: ланки постійного струму ( некерованого випрямляча ), силового імпульсного інвертора і системи управління.

Ланку постійного струму складається з некерованого випрямляча і фільтра. Змінна напруга мережі живлення перетвориться в ньому в напругу постійного струму.

Силовий трифазний імпульсний інвертор складається 3 шести транзисторних ключів. Кожна обмотка електродвигуна підключається через відповідний ключ до позитивного і негативного висновків випрямляча. Інвертор здійснює перетворення випрямленої напруги в трифазне змінну напругу потрібної частоти і амплітуди , яке прикладається до обмоток статора електродвигуна .

У вихідних каскадах інвертора в якості ключів використовуються силові IGBT - транзистори . У порівнянні з тиристорами вони мають більш високу частоту перемикання, що дозволяє виробляти вихідний сигнал синусоїдальної форми з мінімальними спотвореннями.

\section{Принцип роботи перетворювача частоти}

Перетворювач частоти складається з некерованого діодного силового випрямляча В, автономного інвертора , системи управління ШІМ, системи автоматичного регулювання, дроселя Lв i конденсатора фільтра Св. Регулювання вихідної частоти fвих . і напруги U вих здійснюється в инвертор за рахунок високочастотного широтноімпульсного управління . 
Широтно - імпульсне управління характеризується періодом модуляції, усередині якого обмотка статора електродвигуна підключається по черзі до позитивного і негативного полюсів випрямляча.

Тривалість цих станів всередині періоду ШІМ модулюється за синусоїдальним законом. При високих (зазвичай 2 ... 15 кГц) тактових частотах ШІМ , в обмотках електродвигуна , внаслідок їх фільтруючих властивостей , течуть синусоїдальні струми.

Таким чином, форма кривої вихідної напруги являє собою високочастотну двухполярную послідовність прямокутних імпульсів . Частота імпульсів визначається частотою ШІМ , тривалість ( ширина) імпульсів протягом періоду вихідний частоти АІН промодулі - рована за синусоїдальним законом . Форма кривої вихідного струму (струму в обмотках асинхронного електродвигуна ) практично синусоїдальний .

Регулювання вихідної напруги інвертора можна здійснити двома способами: амплітудним (АР) за рахунок зміни вхідної напруги Uв і широтно -імпульсним ( ШИМ) за рахунок зміни програми перемикання вентилів V1- V6 при Uв $=$ const .

Другий спосіб отримав поширення в сучасних перетворювачах частоти завдяки розвитку сучасної елементної бази (мікропроцесори, IBGT-транзистори). При широтно-імпульсної модуляції форма струмів в обмотках статора асинхронного двигуна виходить близької до синусоїдальної завдяки фільтруючим властивостям самих обмоток.

Таке управління дозволяє отримати високий ККД перетворювача і еквівалентно аналоговому управлінню за допомогою частоти і амплітуди напруги.

Сучасні інвертори виконуються на основі повністю керованих силових напівпровідникових приладів замикаються GTO - тиристорів , або біполярних IGBT - транзисторів з ізольованим затвором.

Вона складається з вхідного ємнісного фільтра СФ і шести IGBT - транзисторів V1- V6 включеними зустрічно паралельно діодами зворотного струму D1- D6.

За рахунок почергового перемикання вентилів V1- V6 за алгоритмом , заданим системою управління , постійне вхідний напруга Uв перетворюється в змінну прямоугольно -імпульсне вихідна напруга . Через керовані ключі V1V6 протікає активна складова струму асинхронного електродвигуна, через діоди D1- D6 - реактивна складова струму.

\title{
Література
}

1. Википедия-URL: http://ru.wikipedia.org/wiki/Частотный_преобразователь

2. URL: http://www.technowell.ru/main-about-invertor/

3. URL: http://www.moeller.ru/wiringmanual/drives079.html/

4. URL: http://artesk.ru/invertor_shema.html

\section{„Самое оригинальное и одно из самых нравственных чувств нашего века, века науки, это чувство искреннего сомнения”}

\author{
(Гюйо Ж.)
}

